\title{
Association Between the Immune System Response and Body Mass Index Among Hepatitis C Virus Saudi Patients
}

Osama H. Al-Jiffri

Department of Medical Laboratory Technology, Faculty of Applied Medical Sciences, King Abdulaziz University, Saudi Arabia.

Eur J Basic Med Sci 2015;5(4): 61-66

Received: 16-01-2016

Accepted: 10-06-2016
Correspondence (Yazıșma Adresi): Dr. Osama H. Al-Jiffri

Department of Medical Laboratory Technology, Faculty of Applied Medical Sciences, King Abdulaziz University, P.O. Box 80324, Jeddah, 21589, Saudi Arabia. E-mail:dr_jiffri1@outlook.com

\begin{abstract}
Recently, about $2.35 \%$ of the world population, are estimated to be chronically infected with hepatitis C virus (HCV). However, the role of immune system dysfunction happening in state of obesity among HCV is poorly understood. The purpose of this study was to determine the strength of the association between the human immune response and body mass index (BMI) and whether differences exist in the effects of obesity on selected immune parameters among HCV Saudi patients. Two hundred non-hypertensive, non-cirrhotic Saudi patients with chronic HCV infection; Patients were divided in to two equal groups according to their body mass index : Group (A): Included HCV patients with a BMI more than $25 \mathrm{~kg} / \mathrm{m}^{2}$ (the obese group). Group (B): Included HCV patients with a BMI between 18.5 and $23 \mathrm{~kg} / \mathrm{m}^{2}$ (the normal-weight group). Parameters CD3, CD4 and CD8 were quantified. Leukocyte and differential counts were performed. We observed elevation with regard to the normal weight group in the parameters of white blood cells, neutrophils, monocytes, CD3, CD4 and CD8 for group A. CD3, CD4 and CD8 correlated with BMI only as a total amount, as well as with all measured parameters of blood count. There is a strong association between BMI and the human immune system among $\mathrm{HCV}$ patients.
\end{abstract}

Key Words: Immune System; Obesity; Body Mass Index; Hepatitis C Virus Infection.

Hepatit C Virüslü Suudi Hastalarda Immun Cevap ve Vücut Kitle Indeksi Arasındaki ilișki

\section{ÖZET}

Son zamanlarda, dünya nüfusunun yaklașık \% 2.35, hepatit C virüsü (HCV) ile kronik olarak enfekte olduğu tahmin edilmektedir. Bununla birlikte, HCV'nin obezite durumunda gerçekleșen bağışıklık sistemi bozukluğundaki rolü tam olarak anlașılamamıștır. Bu çalıșmanın amacı, Suudi hastalarda immun cevap ve vücut kitle indeksi (VKi) arasındaki ilișkiyi ve seçilmiş bağıșıklık parametreleri üzerine obezitenin etkilerinin mevcut olup olmadığını belirlemektir. Kronik HCV enfeksiyonu olan sirotik olmayan, hipertansiyonu olmayan iki yüz Suudi hasta; Hastalar vücut kitle endeksine göre iki eșit gruba ayrıldı: Grup (A): VKI $25 \mathrm{~kg} / \mathrm{m}^{2}$ 'den daha fazla olan HCV'li hastalar (obez grup). Grup (B): VKI 18.5 ve $23 \mathrm{~kg} / \mathrm{m}^{2}$ arasinda olan HCV'li hastalar (normal kilolu grubu). CD3, CD4 ve CD8 parametreleri ölçüldü. Lökosit ve diferansiyel sayımları yapıldı. A 
grubu için, beyaz kan hücreleri, nötrofiller, monositler, CD3, CD4 ve CD8 parametrelerinde, normal kilolu gruba göre bir yükselme gözlenmiștir. VKi sadece CD3, CD4 ve CD8 ile değil, keza kan sayımında ölçülen tüm parametreler ile ilișkili idi. HCV hastalarında, VKi ve bağıșıklık sistemi arasında güçlü bir ilișki vardır.

Anahtar Kelimeler: Bağıșıklık Sistemi; Obezite; Vücut Kitle Indeksi; Hepatit C Virüs Enfeksiyonu.

\section{INTRODUCTION}

Globally, an estimated 180 million people are chronically infected with HCV and 3 to 4 million are newly infected each year $(1,2)$. Hepatitis $C$ virus $(\mathrm{HCV})$ infection is one of the main causes of chronic liver disease worldwide (3) and persistent infection occurs in 50 to $80 \%$ of those infected and may lead to the development of cirrhosis and subsequent hepatocellular carcinoma (1). The progression of HCV involves changes in the cellular immunity of those affected $(4,5)$. Some studies have indicated that the cellular immunity of HCV patients undergoes alterations, leading to poor immunological responses or dysfunctions $(6,7)$.

Obesity has also been associated with decreased immune system competence as it alters innate and adaptive immunity and immunity deterioration is related to the grade of obesity (8). Moreover, impaired immune responses have also been suggested to occur in obese humans. Studies indicated that the incidence and severity of certain infections are higher in obese individuals when compared to lean people (9). Retrospective and prospective studies showed obesity to be an independent risk factor for infection after trauma $(10,11)$. In a prospective cohort study of critically ill trauma patients, obese patients had more than two fold increased risk of acquiring infection (12). Also, Renehan et al. demonstrated an association of obesity with $25-40 \%$ of certain malignancies in both obese men and women (13).

Many authors reported dysregulation and alteration in number of immune cells in obese subjects. Obese subjects showed either increased or decreased total lymphocytes in peripheral blood populations (14) and had decreased CD8+ $T$ cell population along with increased or decreased CD4+T cells (15). So, The purpose of this study was to determine whether differences exist in the effects of obesity on selected immune parameters among HCV Saudi patients.

\section{MATERIAL AND METHOD}

\section{Subjects and Methods}

Two hundred non-hypertensive, non-cirrhotic Saudi patients with chronic HCV infection; their age ranged from 25 to $38(30.42 \pm 4.16)$ years, were studied on referral to Gastroenterology and Hepatology Department, King Abdulaziz University Teaching Hospital, Saudi Arabia. All these patients were anti HCV positive by enzyme-linked immunosorbent assay (ELISA). None of the patients included in this study had other potential causes of liver disease, such as alcoholism or autoimmune phenomena. All the patients were not treated previously with antiviral drugs. Only patients diagnosed with chronic HCV monoinfection and have anti HCV antibodies by ELISA were selected to undergo Real-Time polymerase chain reaction (RT-PCR) and were treated with combined pegylatedinterferon--alfa (PEG-IFNa)-ribavirin therapy. This study was a single blind randomized controlled trial where the persons in the lab doing tests were not aware of the subjects' groups. Moreover, the present study was approved by the Scientific Research Ethical Committee, Faculty of Applied Medical Sciences at King Abdulaziz University. All participants were free to withdraw from the study at any time. If any adverse effects had occurred, the experiment will be terminated and the Human Subjects Review Board will be informed. However, no adverse effects occurred, and so the data of all the participants were available for analysis.

Patients were divided in to two equal groups according to their body mass index: Group (A): Included HCV patients with a BMI more than $25 \mathrm{~kg} / \mathrm{m}^{2}$ (the obese group). Group (B): Included HCV patients with a BMI between 18.5 and $23 \mathrm{~kg} / \mathrm{m}^{2}$ (the normal-weight group).

\section{Methods}

\section{Evaluated Parameters}

Real-Time polymerase chain reaction (RT-PCR): Ten milliliter blood samples were collected from each participant at study entry. The blood samples were obtained using disposable needles and heparinized vacuum syringes and stored at $-70^{\circ} \mathrm{C}$ until assayed. Serum samples of all participants were tested for Real-Time polymerase chain reaction (RT-PCR) to detect serum HCV RNA levels by polymerase chain reaction using the COBAS TaqMan HCV test, v2.0 (Roche Diagnostics, Indianapolis, NJ, USA).

Analysis of peripheral blood cells: The analysis of pe- 
Table 1. Comparison of clinical data between both groups.

\begin{tabular}{lll}
\hline & Group $(\mathrm{A})$ & Group $(\mathrm{B})$ \\
\hline Age (year) & $30.42 \pm 3.16$ & $28.87 \pm 3.54$ \\
Height $(\mathrm{cm})$ & $164.16 \pm 5.18$ & $163.14 \pm 4.72$ \\
Body weight $(\mathrm{kg})$ & $82.44 \pm 3.37^{*}$ & $63.85 \pm 2.93$ \\
BMl $\left(\mathrm{kg} / \mathrm{m}^{2}\right)$ & $30.74 \pm 3.61^{*}$ & $21.88 \pm 2.12$ \\
Waist circumference $(\mathrm{cm})$ & $93.91 \pm 4.73^{*}$ & $72.62 \pm 4.86$ \\
Fat mass $(\mathrm{kg})$ & $24.22 \pm 2.95^{*}$ & $13.43 \pm 2.14$ \\
ALT $(\mathrm{U} / \mathrm{L})$ & $65.11 \pm 7.91^{*}$ & $32.32 \pm 6.75$ \\
Albumin $(\mathrm{gm} / \mathrm{dl})$ & $3.82 \pm 0.89$ & $3.27 \pm 0.78$ \\
FPG $(\mathrm{mg} / \mathrm{dL})$ & $115.45 \pm 12.45$ & $107.65 \pm 10.37$ \\
Hb $(\mathrm{gm} / \mathrm{dl})$ & $12.16 \pm 1.52$ & $12.09 \pm 1.31$ \\
Total Bilirubin $(\mathrm{mg} / \mathrm{dl})$ & $1.34 \pm 0.86$ & $1.22 \pm 0.82$ \\
SBP $(\mathrm{mm} \mathrm{Hg})$ & $123 \pm 13.17$ & $120 \pm 12.95$ \\
DBP $(\mathrm{mm} \mathrm{Hg})$ & $83 \pm 8.11^{*}$ & $76 \pm 8.32$ \\
HCV viral load $(\mathrm{IU} / \mathrm{mL})$ & $7.36 \pm 3.52 \times 10^{6 *}$ & $1.74 \pm 3.38 \times 10^{6}$ \\
& & \\
\hline
\end{tabular}

BMI : Body Mass Index ; Hb : Hemoglobin; FPG: Fasting Blood Glucose; ALT :Alanine aminotransferase; SBP: Systolic blood pressure; DBP: Diastolic blood pressure; $\left(^{*}\right)$ indicates a significant difference between the two groups, $\mathrm{P}<0.05$.

ripheral blood cells (e.g., total and differential count) was performed on a Beckman Coulter AcT 5diff hematology analyzer. The values are expressed in percentages and absolute numbers.

Flow cytometry analysis: The human leukocyte differentiation antigens CD3, CD4 and CD8 (Beckman Coulter, Marseille, France) Five microliters of appropriate monoclonal antibody was added to $50 \mu \mathrm{L}$ of a whole-blood sample and incubated for 15 minutes at room temperature. Thereafter, the erythrocytes were lysed with $125 \mu \mathrm{L}$ of a lysing solution, Optilyse $C$, for 10 minutes. The reaction was stopped by the addition of $250 \mu \mathrm{L}$ phosphate-buffered saline. The samples were analyzed by flow cytometry using Cytomics FC 500 and CXP software (Beckman Coulter). The leukocyte subsets were defined by forwardand side-scatter pattern. The negative control value was determined by a fluorescence background and antibodynonspecific staining.

Body mass index (BMI): Weight and height scale (Metrotype -England) was used to measure weight and height to calculate the body mass index (BMI). Body mass index was calculated by dividing the weight in kilograms by the square of the height in meters $\left(\mathrm{kg} / \mathrm{m}^{2}\right)$. According to the WHO classification, a BMI of $<18.5 \mathrm{~kg} / \mathrm{m}^{2}$ is under weight, $18.5-24.9 \mathrm{~kg} / \mathrm{m}^{2}$ is normal $25-29.9 \mathrm{~kg} / \mathrm{m}^{2}$ is overweight. A BMI of $>30 \mathrm{~kg} / \mathrm{m}^{2}$ is classified as obese and this group was further divided into moderate obesity (30-34.9 $\left.\mathrm{kg} / \mathrm{m}^{2}\right)$, sever obesity $\left(35-39.9 \mathrm{~kg} / \mathrm{m}^{2}\right)$ and very sever obesity $\left(\leq 40 \mathrm{~kg} / \mathrm{m}^{2}\right)(16)$.

\section{Statistical analysis}

Independent t-test was used to compare differences between both groups. Statistical analysis of data was performed using SPSS (Chicago, IL, USA) version 17. The relationship between continuous variables and BMI was assessed by Pearson or Spearman rank correlation. All data were expressed as the mean \pm SD. $P<0.05$ indicated statistical significance.

\section{RESULTS}

The demographic and clinical characteristics of the subjects are shown in Table 1. The mean age of the obese group was $30.42 \pm 3.16$ years, and the mean age of the normal weight group was $28.87 \pm 3.54$ years. There was no significant age, height, albumin, fasting blood glucose, hemoglobin, total bilirubin , systolic blood pressure difference between the obese and normal-weight groups. However, body weight, body mass index (BMI), waist circumference, fat mass, alanine aminotransferase (ALT), diastolic blood pressure and HCV viral load were significantly different between the obese and normal-weight groups. The obese group had a significantly higher fat mass determined by bioelectric impedance. 
Table 2. Mean value and significance of white blood cells, total neutrophil, monocytes, CD3, CD4 and CD8 count of group (A).

\begin{tabular}{lll}
\hline & Group $(\mathrm{A})$ & Group $(\mathrm{B})$ \\
\hline $\begin{array}{l}\text { White blood cells count } \\
\left(10^{9} / \mu \mathrm{L}\right)\end{array}$ & $8.87 \pm 2.59^{*}$ & $6.15 \pm 2.43$ \\
$\begin{array}{l}\text { Total neutrophil count } \\
\left(10^{9} / \mu \mathrm{L}\right)\end{array}$ & $5.85 \pm 1.23^{*}$ & $3.54 \pm 1.18$ \\
Monocytes $\left(10^{9} / \mu \mathrm{L}\right)$ & $0.62 \pm 0.24^{*}$ & $0.43 \pm 0.15$ \\
$\mathrm{CD} 3$ count $\left(10^{9} / \mathrm{L}\right)$ & $1.96 \pm 0.83^{*}$ & $1.57 \pm 0.42$ \\
DC4 count $\left(10^{9} / \mathrm{L}\right)$ & $1.22 \pm 0.47^{*}$ & $0.96 \pm 0.41$ \\
CD8 count $\left(10^{9} / \mathrm{L}\right)$ & $0.75 \pm 0.28^{*}$ & $0.48 \pm 0.25$ \\
\hline
\end{tabular}

$\left({ }^{*}\right)$ indicates a significant difference between the two groups, $\mathrm{P}<0.05$.

The number of white blood cells, total neutrophil count, monocytes, CD3, CD4 and CD8 were significantly elevated in obese individuals when compared with normal controls (Table 2). The Pearson's correlation coefficients test for the relationship between body mass index and white blood cells, total neutrophil count, monocytes, CD3, CD4, CD8 in both groups showed a strong direct relationship in both groups (Table 3, 4).

\section{DISCUSSION}

Previous cohort studies indicated that obesity increases risk of hepatic steatosis and fibrosis in non-diabetic patients with chronic hepatitis $\mathrm{C}$ infection due to diminished response to antiviral therapy and as a result obesity is considered as an important factor in the progression of chronic HCV $(17,18)$. As the impact of obesity on the immune system in the HCV is unknown, our study was conducted to explore the association between the obesity and immune system in obese HCV Saudi patients.

In our study, obese HCV Saudi patients showed increased number of white blood cells, total neutrophil count, monocytes, CD3, CD4 and CD8 than HCV patients with normal body weight, also there was a strong direct relationship between body mass index and white blood cells, total neutrophil count, monocytes, CD3, CD4, CD8 in both groups. Our findings are in line with the results of many previous studies as Moulin et al. who showed in his study that obesity is associated with the modulation of immune parameters (19), elevated numbers of circulating immune cells as neutrophil, monocyte, leukocyte and total WBC (20), as well as elevated activation levels of certain WBC and suppressed immune cell function (14). Also, several authors have reported a chronic inflammation status in individuals with higher BMI (21-23). Which was associated with elevated amounts of white blood cells, neutrophils, and monocytes in the blood of all participants with BMI higher than that of the control group (24).

Altered immune system response in obese subjects may be related to hyperinsulinemia and insulin resistance associated with obesity. Insulin receptors are present on monocytes and activated $\mathrm{T}$ lymphocytes and insulin signaling modulates $\mathrm{T}$ cell activation and function by inducing glucose uptake, amino acid transport and lipid metabolism (25). Further, as insulin has been shown to promote anti-inflammatory $T$ helper type 2 cell phenotype insulin resistance enhances $T$ helper type 1 cell development (26).

Another cause for immunomodulation in obesity is reduction in lymphocyte proliferative response to mitogen stimulation and dysregulated cytokine expression (15) as Chandra and Kutty found lower lymphoproliferative response to mitogens, impairment of delayed cutaneous hypersensitivity and a decrease in intracellular bacterial killing capacity by neutrophils in obese children and adolescents (27). Moriguchi and cols proposed that the decreased lymphoproliferative response observed in obese rats may be, in part, due to decreased glucose uptake as the main energy source for proliferation of lymphocytes (28). These authors showed that obese rats have a decreased expression of glucose transporter 1 (GLUT-1),

Table 3. Shows the Pearson's correlation coefficients test value and the relationship between the BMI and white blood cells, total neutrophil, monocytes, CD3, CD4 and CD8 count in group (A).

\begin{tabular}{ll}
\hline & Pearson's value $(r)$ \\
\hline White blood cells count $(109 / \mu \mathrm{L})$ & $0.315^{*}$ \\
Total neutrophil count $(109 / \mu \mathrm{L})$ & $0.238^{*}$ \\
Monocytes $(109 / \mu \mathrm{L})$ & $0.252^{*}$ \\
CD3 count $(109 / \mathrm{L})$ & $0.233^{*}$ \\
DC4 count $(109 / \mathrm{L})$ & $0.224^{*}$ \\
CD8 count $(109 / \mathrm{L})$ & $0.229^{*}$
\end{tabular}

Significance was calculated by Spearman or Pearson correlation (2-tailed), ${ }^{*} p<0.05 ; r$, correlation coefficient. 
Table 4. Shows the Pearson's correlation coefficients test value and the relationship between the BMI and white blood cells, total neutrophil, monocytes, CD3, CD4 and CD8 count in group (B).

\begin{tabular}{ll}
\hline & Pearson's value $(r)$ \\
\hline White blood cells count $\left(10^{9} / \mu \mathrm{L}\right)$ & $0.293^{*}$ \\
Total neutrophil count $\left(10^{9} / \mu \mathrm{L}\right)$ & $0.225^{*}$ \\
Monocytes $\left(10^{9} / \mu \mathrm{L}\right)$ & $0.231^{*}$ \\
CD3 count $\left(10^{9} / \mathrm{L}\right)$ & $0.226^{*}$ \\
CD4 count $\left(10^{9} / \mathrm{L}\right)$ & $0.217^{*}$ \\
CD8 count $\left(10^{9} / \mathrm{L}\right)$ & $0.218^{*}$ \\
\hline
\end{tabular}

Significance was calculated by Spearman or Pearson correlation

(2-tailed), ${ }^{*} \mathrm{p}<0.05 ; \mathrm{r}$, correlation coefficient.

which is expressed on the immune cells membranes after mitogen stimulation. However, further investigation is needed to determine if this is the case in humans as well.

Our findings indicated an association between BMI and cell subpopulation counts in peripheral blood. In the whole tested population we denote an increase of white blood cells, neutrophils, monocytes, CD3, CD4 and CD8 counts. We agree with the suggestion of Kintscher et al. observed an increased number of CD3 and CD4 lymphocytes in the peripheral blood of obese women correlating with BMI (29). Also, Antuna-Puente et al. found that $\mathrm{BMI}$ is positively correlated with the number of macrophages in adipose tissue (30). Finally, within the limit of this study, weight reduction is recommended for modulation of immune system response among obese patients with HCV. Further researches are needed to explore the impact of weight reduction on immune system response among obese patients with HCV.

\section{Conclusion}

There is a strong association between $\mathrm{BMI}$ and the human immune system among HCV patients, so an integrated treatment approach is essential to correct the immune system incompetence through medications, life style change and exercise training program.

\section{Acknowledgment}

This work was funded by the Deanship of Scientific Research (DSR), King Abdulaziz University, Jeddah, under grant No. (142-568-D1435). The authors, therefore, acknowledge with thanks DSR technical and financial support.

\section{REFERENCES}

1. Rosen H. Clinical practice. Chronic hepatitis $C$ infection. $N$ Engl J Med 2011; 364:2429-38.

2. Sheridan $D$, Neely $R$, Bassendine M. Hepatitis $C$ virus and lipids in the era of direct acting antivirals (DAAs). Clinics and Research in Hepatology and Gastroenterology 2013;37:10-16.

3. European Association for the Study of the Liver. EASL Clinical Practice Guidelines: Management of hepatitis C virus infection. Journal of Hepatology 2014; 60:392-420.

4. Rehermann B, Nascimbeni M. Immunology of hepatitis $B$ virus and hepatitis $C$ virus infection. Nat Rev Immunol 2015;5:215-29.

5. Barnes $E$, Lauer $G$, Walker B, Klenerman $P$. T cell failure in hepatitis C virus infection; Viral Immunol 2002;15: 285-93.

6. Penna A, Missale G, Lamonaca V, PilliM C, Mori C, Zanelli P. Intrahepatic and circulating HLA class II-restricted, hepatitis $C$ virus-specific $T$ cells: functional characterization in patients with chronic hepatitis C. Hepatology 2002;35:1225-36.

7. Rico M, Quiroga J, Subira D, Garcia E, Castanon S, Sallberg $M$. Features of the CD4+ T-cell response in liver and peripheral blood of hepatitis $C$ virus-infected patients with persistently normal and abnormal alanine aminotransferase levels. J Hepatol 2002;36:408-16.

8. Marti A, Marcos A Martinez J. Obesity and immune function relationships. Obes Rev 2001;2:131-40.

9. Karlsson E, Beck M. The burden of obesity on infectious disease. Exp Biol Med 2010; 235:1412-24.

10. Serrano $P$, Khuder $S$, Fath J. Obesity as a risk factor for nosocomial infections in trauma patients. J Am Coll Surg 2010; 211:61-67.

11. Edmonds R, Cuschieri J, Minei J, Rosengart M, Maier R. Body adipose content is independently associated with $a$ higher risk of organ failure and nosocomial infection in the non-obese patient post-injury. J Trauma 2011;70:292-298.

12. Bochicchio G, Joshi M, Bochicchio K, Nehman S, Tracy J. Impact of obesity in the critically ill trauma patient: a prospective study. J Am Coll Surg 2006;203 :533-538.

13. Renehan A, Tyson M, Egger M, Heller R, Zwahlen M. Bodymass index and incidence of cancer: a systematic review and meta-analysis of prospective observational studies. 
Lance 2008;371:569-78.

14. Nieman D, Henson D, Nehlsen-Cannarella S, Ekkens M, Utter A. Influence of obesity on immune function. J Am Diet Assoc 1999;99:294-299.

15. O'Rourke R, Kay T, Scholz M, Diggs B, Jobe B. Alterations in $T$-cell subset frequency in peripheral blood in obesity. Obes Surg 2005; 15:1463-1468.

16. Han S, Jeon $K, \operatorname{Kim} M, \operatorname{Kim} H$, Lee A. Obesity with a body mass index under 30 does not significantly impair the immune response in young adults. Nutrition Research 2011;31:362-369.

17. Lo lacono O, Venezia G, Petta S, Mineo C, De Lisi S. The impact of insulin resistance, serum adipocytokines and visceral obesity on steatosis and fibrosis in patients with chronic hepatitis C. Aliment Pharmacol Ther 2007;25:1181-1191.

18. Delgado-Borrego A, Healey $D$, Negre B, Christofi $M$, Sabharwal S. Influence of body mass index on outcome of pediatric chronic hepatitis $C$ virus infection. J Pediatr Gastroenterol Nutr 2010;51:191-197.

19. Moulin C, Marguti I, Peron J, Rizzo L, Halpern A. Impact of adiposity on immunological parameters. Arq Bras Endocrinol Metab 2009;53:183-9.

20. Womack J, Tien P, Feldman J. Obesity and immune cell counts in women. Metabolism 2007;56:998-1004.

21. Iyer A, Fairlie D, Prins J, Hammock B, Brown L. Inflammatory lipid mediators in adipocyte function and obesity. Nat Rev Endocrinol 2010; 6:71-82.

22. Stofkova A. Leptine and adiponectin: from energy and metabolic dysbalance to inflammation and autoimmunity. Endocr Regul 2009;43:157-68.
23. Karalis K, Giannogonas P, Kodela E, Koutmani Y, Zoumakis $M$, Teli $T$.Mechanisms of obesity and related pathology: linking immune responses to metabolic stress. FEBSJ 2009;276: 5747-54.

24. Ilavska S, Hor $\square$ thova M, Szabova M, Nemessnyi T, Jahnova E, Tulinska J, Liskova A, Wsolova L, Staruchova M, Volkovova $K$. Association between the human immune response and body mass index. Human Immunology 2012;73:480-485.

25. Trischitta V, Brunetti A, Chiavetta A, Benzi L, Papa V. Defects in insulin-receptor internalization and processing in monocytes of obese subjects and obese NIDDM patients. Diabetes 1989; 38:1579-1584.

26. Maciver N, Jacobs S, Wieman H, Wofford J, Coloff J. Glucose metabolism in lymphocytes is a regulated process with significant effects on immune cell function and survival. J Leukoc Biol 2008;84:949-957.

27. Chandra R, Kutty K. Immunocompetence in obesity. Acta Paediatr Scand 1980; 69:25-30.

28. Moriguchi S, Kato M, Sakai K, Yamamoto S, Shimizu E. Decreased mitogen response of splenic lymphocytes in obese Zucker rats is associated with the decreased expression of glucose transporter 1 (GLUT-1). Am J Clin Nutr $1998 ; 67$ :1124-9.

29. Kintscher $U$, Hartge $M$, Hess $K$, Foryst-Ludwig A, Clemenz $M$, Wabitsch M.T-lymphocyte infiltration in visceral adipose tissue: a primary event in adipose tissue inflammation and the development of obesity-mediated insulin resistance. Arterioscler Thromb Vasc Biol 2008;28:1304-10.

30. Antuna-Puente B, Feve B, Fellahi S, Bastard J. Adipokines: the missing link between insulin resistance and obesity. Diabetes Metab 2008;34:2-11. 